\title{
Investigation of relationship between sediment characteristics and heavy metals across seasons in the Lower Focardos River, Nigeria
}

\section{*11AMINAYANABA, ONARI ASIMIEA ${ }^{2}$ OLANREWAJU LAWAL}

\author{
${ }^{I}$ Departments of Crop and Soil Science, Faculty of Agriculture, \\ University of Port Harcourt, P.M.B 5323, Choba Campus, Port Harcourt \\ ${ }^{2}$ Departments of Geography and Environmental Management, Faculty of Social Sciences, \\ University of Port Harcourt, P.M.B 5323, Choba Campus, Port Harcourt. \\ *minalaurel10@gmail.com
}

\begin{abstract}
The presence and concentration of heavy metals in water bodies may be influenced by human activities. Sediments are the final sink of heavy metals in the water body. This study examined the concentration of heavy metals in the sediments across the outlet of the Forcados. This was intended to examine the relationship between sediment characteristics and heavy metal concentration across the seasons. Samples were taken across two seasons and tested for heavy metals. Correlation analysis was used to test association between sediment characteristics and heavy metal concentration, while Mann-Whitney U test was adopted to test the difference across seasons. Results show that Total Organic Carbon (TOC) and the particle size distribution have a significant relationship $(\mathrm{P}<0.05)$ with correlation coefficient -0.272 and 0.335 for sand and silt respectively. TOC was also found to be positively and significantly correlation with all the heavy metal tested, while $\mathrm{V}, \mathrm{Ni}, \mathrm{Cr}, \mathrm{Pb}, \mathrm{Cu}$ displayed significant correlation with particle size distribution. Across these seasons, significant difference $(\mathrm{P}<0.05)$ was recorded for oil/grease (OGRS), Total Petroleum Hydrocarbon (TPH), TOC, Sand, Clay, $\mathrm{Cr}, \mathrm{Fe}, \mathrm{As}, \mathrm{Ba}$ and $\mathrm{Zn}$. Association between particle size and OGRS gives an indication that, while oil spill in a sandy environment may seep in deeper, the depth of permeation of oil spill in fine particle sediment could be limited. It was concluded there are marked variations in heavy metals across seasons and there is an association between these concentration and the characteristics of the sediment. This understanding is important for prioritization of remediation. CJASEM
\end{abstract}

http://dx.doi.org/10.4314/jasem.v21i1.21

Keywords: Sediments, Pollution, Forcados River, Heavy Metals, TOC, TPH

Forcados River is a major tributary of River Niger that bifurcates off and flow through freshwater swamps, mangrove swamps, and coastal barrier ridges for about $200 \mathrm{~km}$ to empty into the Atlantic Ocean. The river course is characterized by large wetland comprising of sandy beaches, seasonally flooded rainforest, mangrove swamps and mudflats with numerous oil and gas installations. The Forcados River empties into the Atlantic Ocean (Figure 1) at Ogulagha, a community developed on a coastal barrier island in Burutu Local Government Area of Delta State, Nigeria.

Ogulagha and its environment is host to numerous oil wells located onshore and nearshore. The Forcados oil loading terminal is located less than five kilometers nearshore with storage facilities directly at the shore line. Over the years, substantial oil and gas exploration, exploitation activities as well as other anthropic input along the course of the River may have influenced the environment substantially. Several factors, including variations resulting from water discharge and source areas from hydrocarbon storage and transportation operations in the study area may lead to irregular introduction of heavy metals, most probably associated with hydrocarbon, into the aquatic system. The metals may not be readily soluble but become fixed to particulate matter that settles off the water column into the sediment. The metal concentration in the water body therefore decreases as the particulates settles. By this means, the metals and particulate matter that are present in the aqueous phase ultimately sink into the sediments.

Heavy metal contamination has significant impact on the quality of water bodies. The presence of these metals in sediment, provides one of the largest storage of such within this system while also providing a very important role in their transformation (Peng, Song, Yuan, Cui, \& Qiu, 2009). It is extensively demonstrated that increasing heavy metal pollution from various industry constitutes environmental hazard for humans and other living things (Uluturhan \& Kucuksezgin, 2007). 
Waste from various enterprises often either advertently or inadvertently often end up in the environment especially in the water bodies. This often leads to soil contamination, alteration of chemical and physical properties of the soils (Aelion, Davis, McDermott, \& Lawson, 2009). Urban soils have been reported to have elevated concentrations of $\mathrm{Pb}, \mathrm{Cd}, \mathrm{Cu}$, and $\mathrm{Zn}$ in comparison to rural, agricultural or forest soils (Chen, Wong, Zhou, \& Wong, 1997; Pilgrim \& Schroeder, 1997). Furthermore, newer segments of the city were also found to a have lesser concentration in comparison to the older regions (Guo, Wu, Xie, \& Zhang, 2012). All these sources combined with oil and gas activities could lead to elevated levels of heavy metals in water bodies. Essentially, these contaminants may find their way directly to humans through inhalation of dust from contaminated soils, ingestion or skin contact or indirectly through the consumption of plants and/or animals in these contaminated environments. Plants have been found to absorb heavy metals via foliar uptake (Feng et al., 2011). Furthermore, a significant amount of these metals are discharged into water bodies and eventually accumulated and potentially biomagnified along water bodies, sediment and the aquatic food chain (Uluturhan \& Kucuksezgin, 2007) as well as terrestrial food web (Wu, Meng, \& Li, 2005). These processes have been reported to result in sub lethal effect and sometimes death of aquatic organisms (Peng et al., 2009).
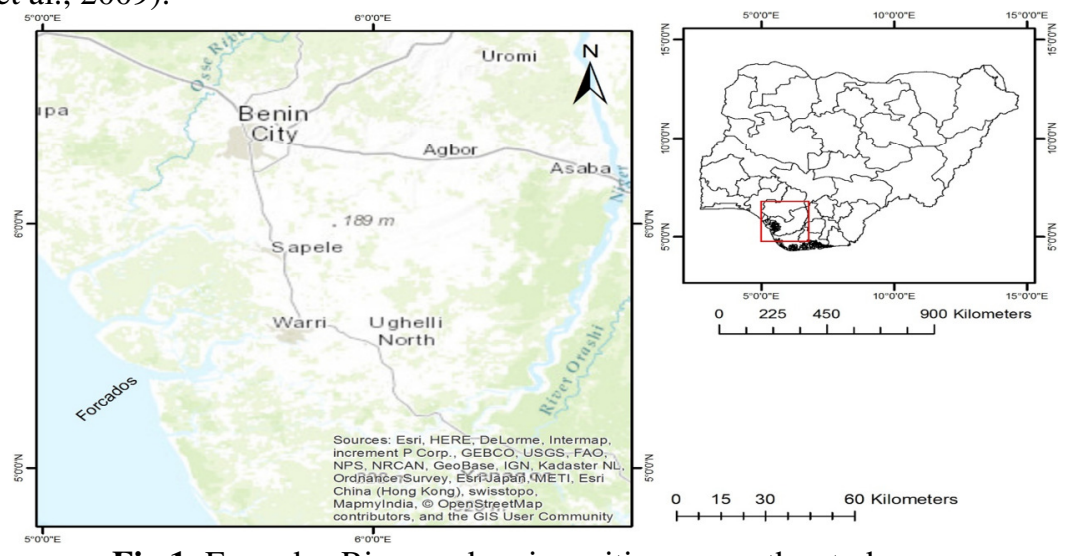

Fig 1: Forcados River and majors cities across the study area

From the foregoing it is evident that, there is need to analyse the distribution of heavy metals in the environment especially in the water systems close to high population as well as industrial regions. This could help in understanding the anthropogenic impacts on the ecosystem as well as supporting risk assessment posed by human activities on this system.

The study is aimed at assessing the relationship between heavy metal concentration and sediment
Heavy metals in sediment usually remain inert and may be released back into the water column if there are disturbances (Olivares-Rieumont et al., 2005). Various studies have identified the sources and impacts of heavy metals e.g. Hossain (2006); Mariaema, Gabriel, and Valentin (2012); Poggio and Vrscaj (2009). Calderon, Ortiz-Perez, Yanez, and Diaz-Barriga (2003) reported that pregnant women and children are the most susceptible to the negative health impacts of heavy metals. Lead for example, has a wide range of sources of exposure especially, through human activities - mining, burning fuels and industrial processes (World Health Organisation, n.d.-b). It is also found in petrol, paints, battery production, solders, stained glass making, some cosmetics \& traditional medicines and when Lead pipes are being used for water delivery (World Health Organisation, n.d.-b). Attendant environmental and health issues in many parts of the world affects many body systems - neurologic, hematologic, gastrointestinal, cardiovascular and renal systems (World Health Organisation, n.d.-a). There has been efforts at the international level to eliminate these heavy metals in products and processes e.g. Global Alliance to Eliminate Lead Paint, Global Mercury Partnership, Bamako Convention, Basel Convention. 


\section{MATERIALS AND METHODS}

Sample Collection: Sediment sample stations were established to reflect the oil and gas activities in the environment. Three stations were located in the main channel of Forcados River opening into the Atlantic Ocean, two stations along the shoreline of the Atlantic and 23 stations near shore, in a radial arrangement. The sampling strategy was to capture pollutants that entre the water bodies from oil installations. A total of 28 locations (Figure 2) were sampled for sediment. An Eckman grab was used to collect bottom sediment. Each study site was geo- referenced with a hand-held GPS - Garmin Etrex model.

Sample Preparation and Analysis: The sediment samples were analyzed for particle size by the method described by Kettler, Doran, and Gilbert (2001). OGRS as well as TPH were determined by ASTM D3921 (Infrared spectrometry) and GC methods respectively. Also, sediment samples were air 2 grams of dry weight were mineralized in analyte grade Nitric acid $\left(\mathrm{HNO}_{3}\right)$ and extracted for determination. Flame Atomic Absorption Spectrophotometer (AAS) was calibrated with various standards for heavy metals and used to determine the concentration of $\mathrm{Mn}, \mathrm{V}, \mathrm{Ni}, \mathrm{Cr}, \mathrm{Fe}, \mathrm{Pb}$, $\mathrm{Cu}$, Ar, Ba and Zn (USEPA, 1991). TOC was determined by the Walkley and Black (1934) method.

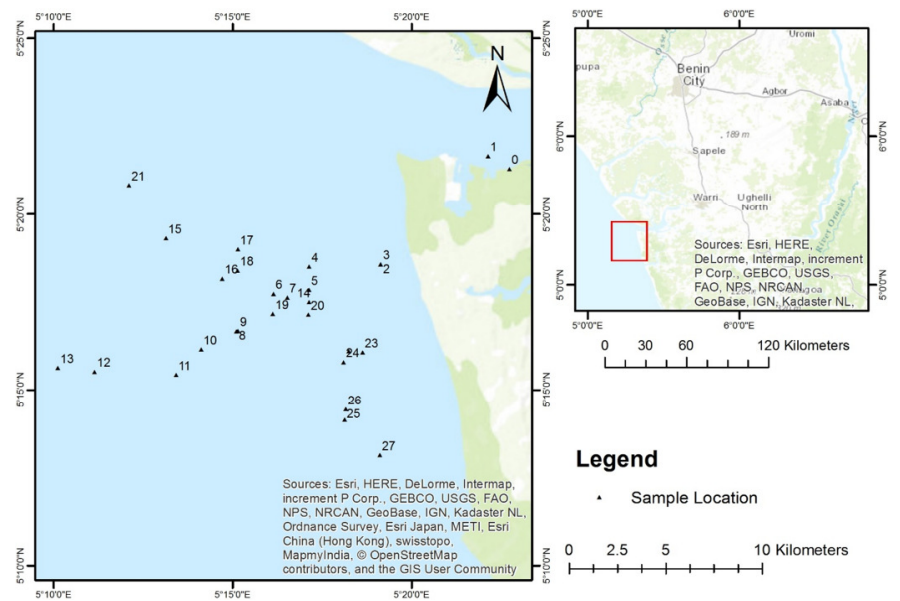

Fig 2: Sampling locations across the outlet of the Forcados River

Statistical Analysis: In the examination of association and variation across seasons among organic matter, particle size distribution and heavy metal contents, data collected for the sediment samples were subjected to non-parametric tests. This was necessary since the sample size is small across the study area (28 samples per season). It is therefore not expected that the dataset will be normally distributed, thus parametric test would be inappropriate. Spearman rank correlation was used to examine the relationship among the different aspect of the dataset. Spearman rank $\mathrm{R}$ is similar to the Pearson product-moment correlation coefficient but it is computed from ranks and its power and efficiency has been recently reviewed by Gibbons and Chakraborti (2014).

In order to examine seasonal variation across the sediment sample properties, Mann U Whitney Tests were carried out. Mann-Whitney $U$ test was employed, as an alternative to the parametric t-test analysis for independent samples. It has been reported to be more sensitive than Wald-Wolfowitz runs test and Kolmogorov-Smirnov two-sample test when non-parametric comparison of two samples is required (Avwiri, Lawal, \& Nwokeoji, 2016). This test allows testing of differences between two groups without the assumption of normal distribution.

\section{RESULTS AND DISCUSSION}

Distribution of measured parameters: Across most of the study area, most the parameters have means for the dry season which are considerably lower than that of the Wet season (Table 1). Moreover, the differences are much more pronounced for OGRS, $\mathrm{TPH}, \mathrm{Mn}$ and $\mathrm{V}$. In the case of $\mathrm{Ni}$ and $\mathrm{Cr}$, the mean values were found to be higher in the dry season compared to the wet season. 
Table 1: Physiochemical Characteristics of Sediment Samples from the Study Area

\begin{tabular}{llllllll}
\hline S/No & Parameter & Dry Season & & \multicolumn{3}{c}{ Wet Season } \\
& & Average & Max & Min & Average & Max & Min \\
\hline 1 & Oil/Grease $(\mathrm{mg} / \mathrm{kg})$ & 35.59 & 61.80 & 14.40 & 106.62 & 713.00 & 35.80 \\
2 & $\mathrm{TPH}(\mathrm{mg} / \mathrm{kg})$ & 26.25 & 45.10 & 10.80 & 78.10 & 520.50 & 26.50 \\
3 & $\mathrm{TOC}(\%)$ & 0.53 & 2.81 & 0.03 & 0.77 & 2.15 & 0.39 \\
4 & $\mathrm{Mn}(\mathrm{mg} / \mathrm{kg})$ & 76.84 & 92.86 & 25.56 & 527.96 & 1560.0 & 115.0 \\
5 & $\mathrm{~V}(\mathrm{mg} / \mathrm{kg})$ & 0.25 & 0.39 & 0.05 & 78.65 & 114.40 & 7.06 \\
6 & $\mathrm{Ni}(\mathrm{mg} / \mathrm{kg})$ & 3.71 & 5.83 & 0.83 & 0.31 & 0.62 & 0.04 \\
7 & $\mathrm{Cr}(\mathrm{mg} / \mathrm{kg})$ & 17.40 & 29.37 & 3.35 & 4.55 & 9.32 & 0.11 \\
8 & $\mathrm{Fe}(\mathrm{mg} / \mathrm{kg})$ & 3441.33 & 3796.0 & 1331.9 & 3713.41 & 4642.10 & 1083.0 \\
9 & $\mathrm{~Pb}(\mathrm{mg} / \mathrm{kg})$ & 4.48 & 7.89 & 0.80 & 6.05 & 18.49 & 0.91 \\
10 & $\mathrm{Cu}(\mathrm{mg} / \mathrm{kg})$ & 2.26 & 6.19 & 0.08 & 2.74 & 8.49 & 0.07 \\
11 & $\mathrm{As}(\mathrm{mg} / \mathrm{kg})$ & 0.13 & 0.38 & 0.02 & 0.16 & 0.30 & 0.00 \\
12 & $\mathrm{Ba}(\mathrm{mg} / \mathrm{kg})$ & 0.45 & 1.34 & 0.08 & 0.55 & 1.05 & 0.08 \\
13 & $\mathrm{Zn}(\mathrm{mg} / \mathrm{kg})$ & 7.31 & 22.82 & 1.38 & 9.08 & 17.85 & 1.42
\end{tabular}

Relationship between organic matter sources and sediment particle size distribution: Correlation analysis was carried out to examine the relationship among oil and grease concentration, TPH and TOC in the sediment in comparison to particle size distribution of the sediment samples collected across the study area. Particle surfaces serve as potential area of adsorption by different cations and anions therefore, the more the surfaces available for these to adhere to, the higher the chances that there would be more of those in the sediments.

Table 2: Relationship between organic matter content and particle size distribution

\begin{tabular}{llll}
\hline & OGRS & TPH & TOC \\
\hline OGRS & 1.000 & $0.998^{* *}$ & $0.307^{*}$ \\
TPH & $0.998^{* *}$ & 1.000 & $0.294^{*}$ \\
TOC & $0.307^{*}$ & $0.294^{*}$ & 1.000 \\
Sand & 0.064 & 0.067 & $-0.272^{*}$ \\
Silt & 0.018 & 0.018 & $0.335^{*}$ \\
Clay & -0.102 & -0.107 & 0.233
\end{tabular}

$\mathbf{N}=56 ; *$ significant at $\mathrm{P}=0.05 ; * *=$ significant at $\mathrm{P}=0.01$

The result shows (Table 2) that there is a strong and positive correlation (0.998) between the TPH content and the OGRS in the sediment. This gives an indication that these two organic matter sources are related and their dynamics in the sediment samples are potentially associated. However, there is a weak but significant relationship between TOC and these two (correlation coefficients of 0.307 and 0.294 for OGRS and TPH respectively). Comparison of the TOC and the particle size distribution shows that for sand and silt, a significant $(\mathrm{P}<0.05)$ correlation coefficient of -0.272 and 0.335 respectively was recorded.

Relation between organic matter sources and heavy metal content: In order to examine the relationship between the organic matter and the heavy metal content of the substrate, a correlation analysis was carried out, and the results is presented in Table 3

Table 3: Correlation between: Organic matter and heavy metal content

\begin{tabular}{lllllllllll}
\hline & $\mathrm{Mn}$ & $\mathrm{V}$ & $\mathrm{Ni}$ & $\mathrm{Cr}$ & $\mathrm{Fe}$ & $\mathrm{Pb}$ & $\mathrm{Cu}$ & $\mathrm{As}$ & $\mathrm{Ba}$ & $\mathrm{Zn}$ \\
\hline OGRS & 0.215 & 0.179 & 0.176 & $-0.753^{* *}$ & $0.328^{*}$ & -0.130 & 0.093 & 0.253 & $0.263^{*}$ & 0.205 \\
TPH & 0.199 & 0.163 & $0.159^{* *}$ & $-0.750^{* *}$ & $0.322^{*}$ & -0.143 & 0.079 & 0.241 & 0.252 & 0.192 \\
TOC & $0.672^{* *}$ & $0.715^{* *}$ & $0.718^{* *}$ & -0.204 & $0.408^{* *}$ & $0.486^{* *}$ & $0.662^{* *}$ & $0.705^{* *}$ & $0.703^{* *}$ & $0.663^{* *}$ \\
\hline
\end{tabular}

$\mathbf{N}=56$; * significant at $\mathrm{P}=0.05 ; * *=$ significant at $\mathrm{P}=0.01$ 
In the case of TOC, there were positive and significant (at both $\mathrm{P}=0.05$ and $\mathrm{P}=0.01$ ) relationship for $\mathrm{Mn}, \mathrm{V}, \mathrm{Ni}, \mathrm{Cu}, \mathrm{As}, \mathrm{Ba}$, and $\mathrm{Zn}$ (Table 2). Furthermore, there is a weak but significant association between TOC and two metals $\mathrm{Fe}$ and $\mathrm{Pb}$ with correlation coefficients of 0.408 and 0.486 respectively.

There is a significantly strong association among TPH, OGRS and Cr. A correlation coefficient of $0.753(\mathrm{P}<0.01)$ was recorded for the association between OGRS and $\mathrm{Cr}$, this gives an indication that there is an inverse relationship between OGRS content of the sediment and $\mathrm{Cr}$ content of the same sediment. A similar relationship was observed for $\mathrm{TPH}$ and $\mathrm{Cr}$ - strong, negative and significant.
Iron $(\mathrm{Fe})$ was found to have weak (correlation coefficient $0.322-0.328$ ) but positively significant $(\mathrm{P}<0.05)$ correlation for OGRS and TPH. Barium (Ba) displayed a significant relationship with OGRS and TPH. In the case of Ba, there is a weak ( $r=0.263$, $\mathrm{P}<0.05)$ but positive correlation with OGRS.

Relationship between particle size distribution and heavy metal content: The influence of particle size heavy metal content of sediments was tested across the sediment samples using correlation analysis. The result (Table 4) shows that across the metals examined, there is a negative correlation between total sand content and heavy metal content in the sediment.

Table 4: Correlation analysis result for particle size distribution and heavy metal content

\begin{tabular}{lllllllllll}
\hline & $\mathrm{Mn}$ & $\mathrm{V}$ & $\mathrm{Ni}$ & $\mathrm{Cr}$ & $\mathrm{Fe}$ & $\mathrm{Pb}$ & $\mathrm{Cu}$ & $\mathrm{As}$ & $\mathrm{Ba}$ & $\mathrm{Zn}$ \\
\hline Sand & -0.194 & $-0.273^{*}$ & $-0.278^{*}$ & $-0.324^{*}$ & -0.140 & $-0.316^{*}$ & $-0.298^{*}$ & -0.179 & -0.161 & -0.172 \\
Silt & 0.227 & $0.276^{*}$ & $0.280^{*}$ & 0.189 & 0.228 & $0.352^{* *}$ & $0.272^{*}$ & 0.165 & 0.163 & 0.180 \\
Clay & 0.187 & $0.275^{*}$ & $0.281^{*}$ & $0.368^{* *}$ & 0.056 & $0.299^{*}$ & $0.311^{*}$ & 0.201 & 0.177 & 0.165 \\
\hline
\end{tabular}

$\mathbf{N}=56 ; *$ significant at $\mathrm{P}=0.05 ; * *=$ significant at $\mathrm{P}=0.01$

This association is more pronounced for $\mathrm{Cr}>\mathrm{Pb}>$ $\mathrm{Cu}>\mathrm{Ni}>\mathrm{V}$ all of which have significant $(\mathrm{P}<0.05)$ but weak relationship with sediment's sand content. However, $\mathrm{Mn}, \mathrm{Fe}$, As, $\mathrm{Ba}$ and $\mathrm{Zn}$ were not significantly related to sand content but were negatively correlated with sand in sediment.

Silt and Clay exhibited similar association observed between sand and heavy metal content, there was no significant relationship between $\mathrm{Mn}, \mathrm{Fe}, \mathrm{As}, \mathrm{Ba}, \mathrm{Zn}$ with Silt and Clay content of the sediment. In addition, $\mathrm{Cr}$ was also found to exhibit no significant correlation with Silt content of the sediment.

For Silt, there is a positive and significant $(\mathrm{P}>0.05)$ association with heavy metal content, however the strength of the association is weak with $\mathrm{Pb}>\mathrm{Ni}>\mathrm{V}$ $>\mathrm{Cu}$. The association was also found to be significant at $\mathrm{P}=0.01$ for $\mathrm{Pb}$ signifying a much stronger association in comparison to other metals. A similar observation was made between Clay content and $\mathrm{Cr}$ in the sediment, with a positive and significant correlation $\quad(\mathrm{r}=0.368, \quad \mathrm{P}<0.01)$. Furthermore, there is a significantly $(\mathrm{P}<0.05)$ positive correlation for the other metals and Clay content with strength of association of $\mathrm{Cu}>\mathrm{Pb}>\mathrm{Ni}>\mathrm{V}$ (with correlation coefficient ranging between 0.275 and $0.311)$.

Exploration of seasonal difference in sediment characteristics: Mann-Whitney $\mathrm{U}$ test was used to test difference in seasons across the parameters tested for the sediment samples collected. From the test only 10 out of the 16 parameters were considered in this study.

Table 5: Summary of significant parameters for seasonal difference test across sediment samples

\begin{tabular}{|c|c|c|c|c|c|c|c|c|c|c|c|}
\hline Statistics & & OGRS & TPH & TOC & Sand & Clay & $\mathrm{Cr}$ & $\mathrm{Fe}$ & As & $\mathrm{Ba}$ & $\mathrm{Zn}$ \\
\hline \multirow{2}{*}{$\begin{array}{l}\text { Mean } \\
\text { Rank }\end{array}$} & Dry & 15.68 & 15.75 & 22.77 & 22.50 & 35.36 & 42.50 & 21.29 & 23.38 & 23.25 & 23.88 \\
\hline & Wet & 41.32 & 41.25 & 34.23 & 34.50 & 21.64 & 14.50 & 35.71 & 33.62 & 33.75 & 33.12 \\
\hline \multicolumn{2}{|c|}{ Mann-Whitney U } & 751.00 & 749.00 & 552.50 & 560.00 & 200.00 & 0.00 & 594.00 & 535.50 & 539.00 & 521.50 \\
\hline \multicolumn{2}{|l|}{ Standard Error } & 61.02 & 61.02 & 60.95 & 61.02 & 61.01 & 58.58 & 61.03 & 60.87 & 61.01 & 61.02 \\
\hline $\begin{array}{l}\text { Standardized } \\
\text { Statistics } \\
\text { Asymptotic }\end{array}$ & $\begin{array}{r}\text { Test } \\
\text { Sig. } \quad(2\end{array}$ & 5.88 & 5.85 & 2.63 & 2.75 & -3.15 & -6.69 & 3.31 & 2.36 & 2.41 & 2.12 \\
\hline Sided) & & 0.00 & 0.00 & 0.01 & 0.01 & 0.00 & 0.00 & 0.00 & 0.02 & 0.02 & 0.03 \\
\hline
\end{tabular}

$\mathbf{N}=\mathbf{2 8}$ per season, for a total $\mathbf{N}$ of 56. 
OGRS has a higher mean rank in the wet season compared to the dry season and this difference represents about $62 \%$ increase from dry season to wet season. In the case of TPH, a similar trend was observed - wet season had higher accumulation (or content) in comparison to dry season. Moreover, the difference was also in the same order of magnitude for OGRS (62\% increase). TOC also showed a significant seasonal difference, with mean rank of wet season showing about $33 \%$ increase over that of the dry season.

There were also seasonal difference in relation to the particle size distribution with Sand and Clay showing significant difference over the two seasons. Sand content showed a high mean rank of $34.5 \%$ for wet season compared to $22.5 \%$ for dry season (representing about 35\% increase), thus showing that sand content are more likely to be higher in the wet season than the dry season. Clay content exhibited an opposing relationship over the season. The mean rank for dry season was found to be higher than that of rainy season, thus from dry to wet season there was a reduction of about $39 \%$ in the Clay content.

Across the metals, only $\mathrm{Cr}$ showed a mean rank in dry season higher than that of wet season. The different between dry and wet season was about $66 \%$ i.e. mean rank in wet season is about $66 \%$ lower than that of dry season. This was in agreement with the significant relationship observed between this metal and Clay (Table 5) as well as the seasonal difference for clay content (Table 5). For the other metals (Fe, $\mathrm{Ar}, \mathrm{Ba}$, and $\mathrm{Zn}$ ) wet season mean rank were found to be higher than that of dry season. In the case of Fe, there is about $40 \%$ increase between dry and wet season, while there is about $30 \%, 31 \%$ and $28 \%$ increases for $\mathrm{Ar}, \mathrm{Ba}$ and $\mathrm{Zn}$ respectively.

\section{RESULT AND DISCUSSION}

Correlation analysis was carried out to examine the relationship among oil and grease concentration, TPH and TOC in the sediment in comparison to particle size distribution of the sediment samples collected across the study area. Particle surfaces serve as potential area of adsorption by different cations and anions therefore, the more the surfaces available for these to adhere to, the higher the chances that there would be more of those in the sediments.

The close relationship observed between OGRS and TPH could be related to hydrocarbon in the environment. A major source of Organic Carbon (OC) in the marine and brackish water is biodegraded material from flora and fauna of terrestrial origin.

The relationship between TOC and sand was weak and negative, that between TOC and silt shows a weak but positive correlation with TOC content. This trend was observed by Raj, Jee, and Panda (2013) who reported positive correlation between sediment particle size and OC concentration in the sediment. Positive correlation of $\mathrm{OC}$ with clay and silt is particle size dependent. Increase in OC with decreases in particle size is also attributed to the increase in surface area of fine particles. Thus, there is likely to be more TOC in the sediment with higher proportion of finer particle size.

In the case of OGRS and TPH, there is no significant relationship between these and the particle size distribution. However, there is a negative relationship between clay content and OGRS and TPH, while this is not a significant relationship there is an indication that finer particle size reduces the permeation of OGRS and TPH into sediment. Thus while surface of sediment could be contaminated, the depth of permeation could be limited in fine particle sediment than in sediment with coarse particle.

Sediments are ultimate sinks of metals and particulate matter that are present in the aqueous phase. Sediment of fine particles, especially clay and silt, are generally rich in organic content and often have higher cation exchange capacities and are able to trap metal in sediment, while sandy type sediments, organically poor sediments have little ability to retain metal ions (Liao, Selim, \& DeLaune, 2009). There is a clear indication that $\mathrm{Mn}, \mathrm{V}, \mathrm{Cu}, \mathrm{As}$, $\mathrm{Ba}$ and $\mathrm{Zn}$ have a strong association with the TOC content in the sediment, thus it could be deduced that when these metals are released into the environment they accumulate in the TOC available in the substrate - sediment.

In this study, the accumulation of the metal species is disproportionately skewed, with less accumulation of $\mathrm{Fe}$ and $\mathrm{Pb}$ while a weak and negative correlation between TOC and $\mathrm{Cr}$ exist. The active uptake of heavy metals by some flora and fauna have been reported by Tangahu et al. (2011). As plants and animal die they release such heavy metals accumulated into the aquatic environment (KabataPendias, 2010). The strong, negative and significant relationship between $\mathrm{Cr}$ and OGRS suggest that the metal is not associated with petroleum hydrocarbon unlike some other metals that have been associated with petroleum hydrocarbon. In this study Nickel and Vanadium show strong positive relationship with petroleum hydrocarbon. This trend is in line with the report of Adhikari (2013).

Iron is one of the very abundant metals of the earth crust. The positive and significant relationship observed in this study does not necessarily associate 
$\mathrm{Fe}$ with petroleum hydrocarbon because $\mathrm{Fe}$ is ubiquitous in the Niger Delta environment.

While Ba may not be directly associated with OGRS and TPH its derivative, barite is used as drilling mud, this may account for the positive relationship. Also, the $\mathrm{Pb}$ content was found to be negatively correlated with OGRS and TPH, but this association is weak and not significant. The principal source of $\mathrm{Pb}$ is weathering of Sulphide ores. Anthropogenic sources include, burning of leaded fuels in automobiles, ore smelting and refining, batteries, lead pipe etc.

Particle size often influences the content of various metals in the different substrate (soil or sediment) as the particle provides surfaces to which metals can adhere, within the substrate. From the foregoing it is evident that, the higher the amount of finer particle in the sediment the higher the accumulation of heavy metals. Further to this, the association depend on the amount of different metals accumulated and the total Silt and Clay content, in essence different metal species have tendencies to be accumulated more by either clay particles or silt particles. For the current study area, $\mathrm{Pb}$ seems to have tendencies to have higher accumulation with increasing Silt content while $\mathrm{Cr}$ exhibit similar trend for increasing Clay content. These relationships seem to determine the affinity and persistence of heavy metal in sediments.

All the organic matter related parameters (OGRS, TPH and TOC) were found to be significantly different from dry to wet season. OGRS has a higher mean rank in the wet season compared to the dry season and this difference represent about $62 \%$ increase from dry season to wet season. Thus, giving an indication that, there is likely to be a significantly higher accumulation in the wet season compared to the dry season. In the case of TPH, a similar trend was observed - wet season had higher accumulation (or content) in comparison to dry season. Moreover, the difference was also in the same order of magnitude for OGRS (62\% increase). TOC also showed a significant seasonal difference, with mean rank of wet season showing about $33 \%$ increase over that of the dry season.

Seasonal variation of material concentration in aquatic environment depend on allochthonous inputs carried into water bodies by storm water and run offs. In essence across the study area, the pattern of $\mathrm{Cr}$ accumulation followed clay content varied significantly between dry and wet seasons. For the other metals ( $\mathrm{Fe}, \mathrm{Ar}, \mathrm{Ba}$, and $\mathrm{Zn}$ ) wet season mean rank were found to be higher than that of dry season. This shows that there is a significant variation in the content of these metal in sediments between seasons in relation to these metals.
Conclusion: OGRS and TPH concentration in sediment of the study area is related to hydrocarbon in the environment. Total Organic Carbon in marine sediments is likely to be from these sources. There is an indication that finer particle size reduce the permeation of OGRS and TPH into sediment. The significance of this is that while oil spill in a sandy environment may seep in deeper, the depth of permeation of oil spill in fine particle sediment could be limited. Higher the amount of finer particle in the sediment leads to higher heavy metal accumulation of heavy metals. There is likely to be a significantly higher accumulation of all the organic matter in the wet season compared to the dry season. The outcome of this investigation provides a framework for prioritizing remediation exercise.

\section{REFERENCES}

Adhikari, P. L. (2013). Vanadium/Nickel Ratio as a Proxy for Oil Contaminated Sediments in the Northern Gulf of Mexico. Northern Gulf of Mexico: AAPG Foundation.

Aelion, C. M., Davis, H. T., McDermott, S., \& Lawson, A. B. (2009). Soil metal concentrations and toxicity: associations with distances to industrial facilities and implications for human health. Sci Total Environ, 407(7), 2216-2223. doi: 10.1016/j.scitotenv.2008.11.033

Avwiri, G. O., Lawal, O., \& Nwokeoji, E. I. (2016). Monitoring of specific activities of long-lived radioactive elements along the MiniOkoro/Oginigba Creek, Port Harcourt. Journal of Applied Science and Environmental Management, 20(1), 25-31.

Calderon, J., Ortiz-Perez, D., Yanez, L., \& DiazBarriga, F. (2003). Human exposure to metals. Pathways of exposure, biomarkers of effect, and host factors. Ecotoxicol Environ Saf, 56(1), 93103.

Chen, T. B., Wong, J. W. C., Zhou, H. Y., \& Wong, M. H. (1997). Assessment of trace metal distribution and contamination in surface soils of Hong Kong. Environmental Pollution, 96(1), 6168. doi: http://dx.doi.org/10.1016/S02697491(97)00003-1

Feng, J., Wang, Y., Zhao, J., Zhu, L., Bian, X., \& Zhang, W. (2011). Source attributions of heavy metals in rice plant along highway in Eastern China. Journal of Environmental Sciences, 23(7), 1158-1164. doi: 
$\underline{\text { http://dx.doi.org/10.1016/S1001-0742(10)60529- }}$ $\underline{3}$

Gibbons, J. D., \& Chakraborti, S. (2014). Nonparametric Statistical Inference, Fourth Edition: Revised and Expanded: Taylor \& Francis.

Guo, G., Wu, F., Xie, F., \& Zhang, R. (2012). Spatial distribution and pollution assessment of heavy metals in urban soils from southwest China. Journal of Environmental Sciences, 24(3), 410418. doi: http://dx.doi.org/10.1016/S10010742(11)60762-6

Hossain, M. F. (2006). Arsenic contamination in Bangladesh-An overview. Agriculture, Ecosystems \& Environment, 113(1-4), 1-16. doi: http://dx.doi.org/10.1016/j.agee.2005.08.034

Kabata-Pendias, A. (2010). Trace elements in soils and plants. Boca Raton: CRC Press.

Kettler, T. A., Doran, J. W., \& Gilbert, T. L. (2001). Simplified Method for Soil Particle-Size Determination to Accompany Soil-Quality Analyses. Soil Sci. Soc. Am. J, 65, 849-852.

Liao, L., Selim, H., \& DeLaune, R. (2009). Mercury adsorption-desorption and transport in soils. Journal of environmental quality, 38(4), 16081616.

Maria-ema, F. C., Gabriel, L., \& Valentin, N. (2012). The assessment of heavy metals concentration in bacau city soil: Necessity and working methods. Journal of Engineering Studies and Research, 18(1).

Olivares-Rieumont, S., de la Rosa, D., Lima, L., Graham, D. W., D' Alessandro, K., Borroto, J., . . . Sánchez, J. (2005). Assessment of heavy metal levels in Almendares River sediments-Havana City, Cuba. Water Research, 39(16), 3945-3953. doi:

http://dx.doi.org/10.1016/j.watres.2005.07.011

Peng, J.-f., Song, Y.-h., Yuan, P., Cui, X.-y., \& Qiu, G.-1. (2009). The remediation of heavy metals contaminated sediment. Journal of Hazardous Materials, 161(2), 633-640.

Pilgrim, W., \& Schroeder, B. (1997). Multi-media concentrations of heavy metals and major ions from urban and rural sites in New Brunswick, Canada. Environmental Monitoring and Assessment, 47(1), 89-108. doi: 10.1023/A:1005799629588

Poggio, L., \& Vrscaj, B. (2009). A GIS-based human health risk assessment for urban green space planning--an example from Grugliasco (Italy). Sci Total Environ, 407(23), 5961-5970. doi: 10.1016/j.scitotenv.2009.08.026

Raj, S., Jee, P. K., \& Panda, C. R. (2013). Textural and heavy metal distribution in sediments of Mahanadi estuary, East coast of India. Indian Journal of Geo-Marine Sciences, 42(3), 370-374.

Tangahu, B. V., Sheikh Abdullah, S. R., Basri, H., Idris, M., Anuar, N., \& Mukhlisin, M. (2011). A review on heavy metals ( $\mathrm{As}, \mathrm{Pb}$, and $\mathrm{Hg}$ ) uptake by plants through phytoremediation. International Journal of Chemical Engineering, 2011.

Uluturhan, E., \& Kucuksezgin, F. (2007). Heavy metal contaminants in Red Pandora (Pagellus erythrinus) tissues from the Eastern Aegean Sea, Turkey. Water Research, 41(6), 1185-1192. doi: http://dx.doi.org/10.1016/j.watres.2006.11.044

USEPA. (1991). Method for the determination of Environmental sample. Washington DC, 20460: United State Environmental Protection Agency, Office of Research and Development.

Walkley, A., \& Black, I. A. (1934). An examination of the Degtjareff method for determining soil organic matter, and a proposed modification of the chromic acid titration method. Soil science, 37(1), 29-38.

World Health Organisation. (n.d.-a). International Programme on Chemical Safety. Retrieved 19th December, 2014, from http://www.who.int/ipcs/assessment/public_healt $\mathrm{h} / \mathrm{lead} / \mathrm{en} /$

World Health Organisation. (n.d.-b). Issue Brief Series: Lead. In Healthy Environments for Children Alliance (Ed.), WHO, HECA. Geneva: WHO.

Wu, J., Meng, X. X., \& Li, K. (2005). Phytoremediation of soils contaminated by lead. Soils, 37(3), 258- 264. 